\title{
Sistem Informasi Manajemen Persediaan Dan Pendistribusian Barang Hotel Nite \& Day Laguna Bintan - Tanjungpinang
}

\author{
Leva Affrillianggi Falihah ${ }^{1}$, Larasati Indriastuti ${ }^{2}$, Oktavianto ${ }^{3}$ \\ 1,2,3 Jurusan Teknik Informatika STT Indonesia Tanjungpinang \\ Jln. Pompa Air No. 28 Tanjungpinang Kepulauan Riau Indonesia \\ ${ }^{1}$ leva_falihah05@yahoo.com \\ 2larasati2912@gmail.com \\ ${ }^{3}$ oktavianto.tjhu@gmail.com
}

\begin{abstract}
Intisari- Untuk memperlancar jalannya operasional perusahaan, perusahaan perlu bisa dapat memanajemen barang yang ada maka dipelukanlah mengetahui jalan masuk dan keluarnya stok barang. Karena semakin majunya perusahaan tersebut maka, semakin banyak dan sulitnya bagian gudang untuk mendata semua stok yang ada. Maka tentu diperlukan suatu teknologi informasi yang dapat membantu jalannya operasional suatu perusahaan, yang bertujuan untuk menjamin keakuratan data yang tepat dan waktu yang tepat. Sistem Informasi Manajemen Persediaan dan Pendistribusian Barang di Hotel Nite \& Day Laguna Bintan Tanjungpinang adalah suatu sarana yang diharapkan dapat membantu dalam hal pengolahan data barang. Sistem informasi ini dibagun dengan menggunakan metode waterfall. Jenis metode ini terdiri dari 6 tahap yaitu perencanaan, analisis, perancangan, implementasi, pengujian, dan pemeliharaan. Aplikasi ini juga menggunkan aplikasi developer Java Netbeans IDE dan database MySQL untuk membangun sistem informasi manajemen tersebut. Hasil penerapan sistem informasi ini menunjukan bahwa aplikasi ini dapat digunakan dalam membantu pekerjaan bagian gudang dalam mengolah data barang diperusahaan terkait. Sehingga dapat membantu kefektifitas dalam pekerjaannya.
\end{abstract}

Kata Kunci : Sistem Informasi, Sistem Informasi Manajemen, Java, NetBeans IDE, MySQL

Abstract-To accelerate company operation, a company must able to manage the stock, need to know the in and out of the stock they have. The bigger the company the more difficult for the store keeper to record all data. So of course the company need a information technology that help the operation of the company, that intend to ensure accuracy of the right data and the right time. Inventory and Distribution Management Information System is a way to expected to help in processing of the stock data. This application is build using the waterfall method. This type of method consists of 6 stages, namely planning, analysis, design, implementation, testing and maintenance. This information system also uses the Java Netbeans IDE and MySQL database to build the stock management application. The results of this information system indicate that this can be used in assisting the work of the warehouse in processing the goods data in the related company. So that it can help effectiveness in its work

Keywords : Information System, Management Information System, Java, NetBeans IDE, MySQL

\section{Pendahuluan}

Perkembangan teknologi di Indonesia pada saat ini semakin berkembang terutama dalam teknologi informasi. Dengan adanya teknologi informasi ini, bisa memudahkan kita untuk belajar dan mendapatkan informasi yang kita butuhkan di mana saja, kapan saja dan dari siapa saja. Sistem informasi berbasis komputer merupakan suatu alat yang dapat menunjang tingkat kelancaran dalam melaksanakan suatu kegiatan, diharapkan segala masalah dapat diatasi dengan mudah. Salah satu pengolahan data yang menggunakan sistem komputerisasi adalah sistem informasi management persediaan dan pendistribusian barang.

Hotel nite \& day Laguna Bintan - Tanjungpinang adalah suatu perusahan yang bergerak dibidang perhotelan yang di kelolah oleh PT. Bintan Pantai Impian Indah yang teletak di Jalan Bintan No.51, Tanjungpinang Kota, Kepulauan Riau. hotel nite \& day Laguna Bintan - Tanjungpinang sebelumnya bernamakan sebagai Hotel Laguna yang kemudian pada desember 2018 ini telah selesai di renovasi dan di rebranding dengan nama unit baru dan konsep yang berbeda yaitu dengan menawarkan budget hotel dengan fasilitas mewah seperti hotel bintang 3 lainnya. hotel nite \& day Laguna Bintan Tanjungpinang ini juga salah satu bagian dari jaringan grup MPHG (Milestone Pasific Hotel Group). Sebuah perusahaan nasional yang menentukan standarisasi brand dan model binis perhotelan di berbagai wilayah di seluruh Indonesia. Dengan semakin meningkatnya tingkat hunian atau occupany pada perusahaan ini maka permintaan barang pada perusahaan tersebut semakin meningkat oleh sebab itu di perlukanlah sebuah sistem informasi yang tepat yang dapat membantu menyelesaikan berbagai perkerjaan dengan efisien terutama pada memanajemen persediaan barang dan pendistribusian barang yang masih menggunakan sistem manual sehingga mengakibatkan banyaknya data tidak akurat.

Dari persoalan tersebut maka penulis mengambil topik "Sistem Informasi Manajemen Persediaan dan Pendistribusian Barang Hotel Nite \& Day Laguna Bintan - Tanjungpinang". Sebuah sistem informasi yang diharapkan akan dapat mengingkatkan efisiensi, keakuratan dan mengintegrasikan data pada seluruh proses manajemen persediaan dan pendistribusian barang. Adapun program yang di usulkan 
guna menanggani masalah yang ada adalah dengan menggunakan program aplikasi Java NetBeans IDE 8.1 dan Mysql Server sebagai database.

\section{Metodologi Penelitian}

\section{A. Metode Pengumpulan Data}

Dalam kegiatan untuk memperoleh data pada penelitian skripsi ini, penulis menggunakan teknik pengumpulan data yang digunakan adalah sebagai berikut:

1. Wawancara

Teknik pengumpulan data dimana penulis melakukan pertanyaan secara terstruktur, penulis memberikan pertanyaan-pertanyaan yang akan dijawab oleh narasumber guna untuk mendapatkan informasi penting yang akan digunakan untuk diimplementasikan kedalam sistem yang akan dibuat.

2. Observasi

Teknik pengumpulan data dimana penulis melakukan proses pengamatan terhadap pelaksanaan kegiatan seharihari dalam pembuatan proposal, dimana dalam proses pengamatan ini dapat diketahui proses kerja kegiatan tersebut.

3. Studi Literatur

pengumpulan data secara tidak langsung dengan melakukan studi di berbagai sumber, jurnal, buku, dokumentasi, internet dan pustaka.

\section{B. Metode Pengembangan Perangkat Lunak}

Metode pengembangan perangkat lunak yang digunakan adalah metode pengembangan waterfall. Waterfall adalah suatu metodologi pengembangan perangkat lunak yang mengusulkan pendekatan terhadap perangkat lunak sistematik dan sekuensial yang dimulai dari tingkat kemajuan sistem pada seluruh analisis, desain, kode, pengujian dan pemeliharaan.

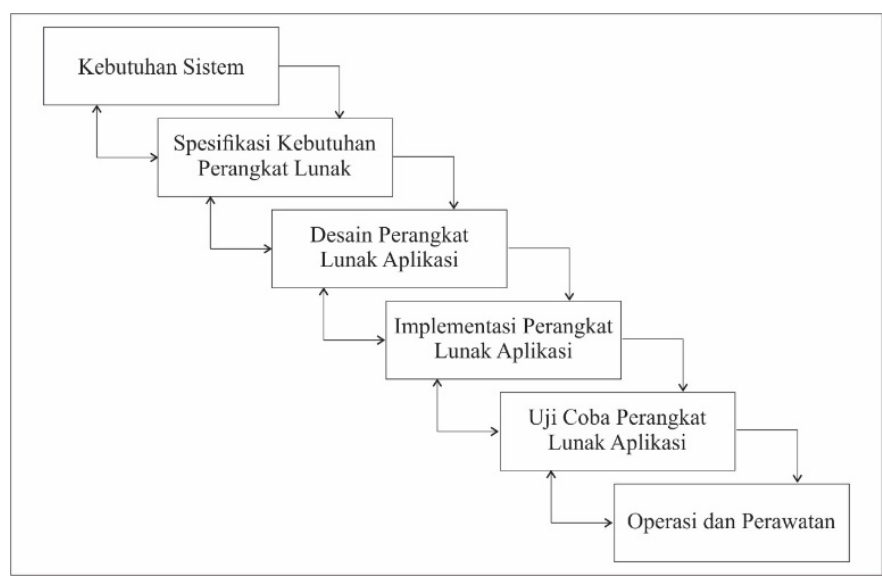

Gambar 1 Model Metodologi Waterfall

Langkah-langkah yang harus dilakukan pada metodologi waterfall :
1. Kebutuhan Sistem

Merupakan proses tahapan awal, untuk mengetahui sifat dan kebutuhan dari program yang akan di buat.

2. Analisa (Analysis)

Melakukan analisis terhadap permasalahan yang di hadapi dan menetapkan kebutuhan perangkat lunak.

3. Perancangan (Design)

Mengubah kebutuhan-kebutuhan diatas menjadi sebuah tampilan program (User Interface) sebelum di mulainya coding.

4. Pembuatan Program/Pengkodean (Coding)

Mengimplementasi hasil analisis dan design ke dalam kode/bahasa pemograman yang di mengerti oleh mesin komputer.

5. Pengujian (Testing)

Setelah selesai mengimplementasi Coding ke Design maka dilakukan kegiatan pengetesan program yang dilakukan oleh programmer. Apakah program tersebut telah berjalan dengan baik dan benar, pengetesan dapat di lakukan dengan cara manual.

6. Perawatan (Maintainance)

Dalam pembuatan sebuah aplikasi, pemeriharaan suatu aplikasi sangatlah di perlukan, karena tidak selamanya aplikasi tersebut hanya begitu saja. Ketika di jalankan mungkin saja masih ada kesalahan kecil yang belum di temukan sebelumnya, ataupun adanya penambahan fiturfitur yang belum ada pada aplikasi tersebut. Sehingga sangat di butuhkan perawatan sistem.

\section{III.Hasil dan Pembahasan}

\section{A. Analisa Sistem}

Sistem Informasi yaitu sistem yang menyediakan informasi untuk menejemen dalam mengambil keputusan dan juga untuk menjalankan operasional sistem dimana sistem tersebut merupakan kombinasi dari orang - orang, teknologi informasi yang berguna bagi si pengguna. Sistem informasi memiliki komponen yang merupakan elemen - elemen yang lebih kecil yang membentuk sistem informasi. Analisa sistem merupakan suatu proses untuk memahami sistem yang ada, mengidentifikasi dan mengevaluasi permasalahan serta hambatan yang terjadi, sehingga dapat memberikan solusi pemecahannya. Analisa sistem dilakukan untuk mengetahui sejauh mana sistem dapat dikembangkan dan diterapkan untuk memperoleh hasil yang maksimal.

\section{B. Analisa Prosedur Yang Sedang Berjalan}

Analisis merupaka suatu kegiatan yang bertujuan untuk mempelajari serta mengevaluasi suatu bentuk permasalahan yang ada pada sebuah sistem, yang merupakan penggambaran perencanaan sekaligus pembuatan sketsa dan beberapa peraturan dari elemen terpisah namun saling berintegrasi ke dalam sutau kesatuan yang utuh. Semua barang yang ada disuatu perusahaan harusnya dilakukan pendataan yang akurat khususnya pada stok barang yang ada. Setiap pemasukan dan 
pengeluaran barang haruslah di data dengan baik dan akurat untuk mengolah semua data stok pada suatu perusahaan yang meliputi berbagai jenis dan aspek yang rumit maka diperlukan suatu aplikasi terkendali untuk mempermudah pengolahannya.

C. Analisa Prosedur Permintaan Pembelian Barang

Untuk lebih jelasnya aliran proses permintaan pembelian barang tersebut dapat dilihat pada flowmap berikut :

1. Departemen bersangkutan membuka form purchase request yang menuliskan list barang permintaan pembelian.

2. Departemen bersangkutan memberikan form purchase request yang telah diisi kepada Purchasing.

3. Purchasing menuliskan harga masing - masing barang permintaan pembelian ke dalam form purchase request yang telah diterima.

4. Purchasing meminta persetujuan kepada departemen bersangkutan dan meminta tanda tangan harga yang telah dimasukan.

5. Purchasing menanda tangani dan meneruskan form purchase request ke pihak akunting untuk memproses approval kepada manager.

6. Pihak akunting mengecek dan mengontrol barang yang akan dibeli

7. Pihak akunting menanda tangani form purchase request sebagai tanda approval dari pihak akunting dan menuruskan nya ke Manager.

8. Pihak akunting memberikan rangkapan form purchase request yang telah setujui dan ditanda tangani oleh manager kepada departemen bersangkutan, purchasing, dan bagian gudang.

D. Analisa Prosedur Permintaan Stok Barang Kepada Bagian Gudang

Menggambarkan aliran atau prosedur yang terjadi pada saat adanya permintaan pembelian barang, dapat dilihat sebagai berikut :

1. Departemen bersangkutan membuka form store requsition yang menuliskan list barang permintaan pengambilan.

2. Departemen bersangkutan menandatangani dan memberikan form store requsition yang telah diisi kepada pihak akunting.

3. Pihak akunting mengecek dan mengontrol barang yang akan dibeli

4. Pihak akunting menanda tangani form store requsition sebagai tanda approval dari pihak akunting dan menuruskan nya ke bagian gudang.

\section{E. Analisa Prosedur Pada Saat Penerimaan Stok Barang}

Menggambarkan aliran yang terjadi pada saat adanya penambahan pada stok barang sebagai berikut :

5. Supplier mengantarkan barang yang dipesan

6. Bagian gudang memeriksa bahwa barang yang diterima sesuai dengan form purchase request dan dengan nota barang pesanan.
7. Bagian gudang menerima barang dan menanda tangani nota barang.

8. Stock Keeper mencatat dan penambahan barang kedalam buku stock dan file Excel.

9. Bagian gudang membuka form penerimaan barang (receiving form)

10. Bagian gudang memberikan rangkapan form penerimaan barang (receiving form) dan nota penerimaan barang kepada bagian akunting.

F. Analisa Prosedur Pengeluaran Stok

Menggambarkan aliran atau prosedur yang terjadi pada saat adanya pengeluaran stok barang, dapat dilihat sebagai berikut :

1. Bagian gudang menerima form store requisition yang telah ditanda tangani.

2. Bagian gudang memberikan barang ke departmen bersangkutan sesuai dengan form store requisition.

3. Departemen bersangkutan menerima barang dan menanda tangani bukti penerimaan pada form store requisition sebelumnya.

4. Bagian gudang memberikan rangkapan form store requisition yang telah di tanda tangan penerimaan kepada departemen bersangkutan dan pihak akunting.

\section{G. Analisa Dokumen}

Berikut beberapa form yang digunakan dalam melakukan proses permintaan pembelian barang, proses penerimaan barang, dan proses permintaan stok barang.

1. Form Permintaan Pembelian Barang (Purchase Request)

Nama Dokumen : Purchase Request

Fungsi : digunakan pada saat department bersangkutan ingin mengajukan permintaan pembelian barang

Jumlah : : 4 Rangkap

Item data : Tanggal, departemen, nomor surat, nama barang, unit, qty, harga unit, total harga, supplier.

2. Form Penerimaan Barang (Receiving Form)

Nama Dokumen : Receiving Form

Fungsi : digunakan pada saat bagian gundang menerima barang dari supplier

Jumlah : 3 Rangkap

Item data : tanggal, departemen, nomor surat, nama barang, unit, qty, harga unit, total harga, supplier.

3. Form Permintaan Stok Barang (Store Requisition)

Nama Dokumen : Store Requisition

Fungsi : digunakan pada saat bagian gundang menerima barang dari supplier

Jumlah : 3 Rangkap 
Item data

\begin{abstract}
tanggal, departemen, nomor surat, nama barang, unit, qty, harga unit, total harga, supplier.
\end{abstract}

\section{H. Analisa Kelemahan Sistem}

Tahap pertama yang dilakukan penulis dalam menganalisis data adalah dengan menentukan permasalahan yang terjadi dalam sistem. Dari hasil pengamatan yang dilakukan penulis pada sistem yang berjalan di Hotel Nite \& Day Laguna Bintan - Tanjungpinag saat ini, terjadi pemborosan kertas sehingga tidak efisien. Penggunaan sistem sudah yang terkomputerisasi akan tetapi belum ada sistem informasi yang mendunkung memproses data, sehingga membuat kinerja dalam proses mengelolah stok barang dan juga pengajuan barang tidak maksimal yang mengakibatkan pendistribusian barang menjadi lambat.

\section{Analisa Kebutuhan Sistem}

Untuk merancang pengembangan sistem secara keseluruhan maka suatu informasi sangat penting, karena dengan informasi kita dapat mengetahui bagian sistem yang akan dilakukan perbaikan dan pergantian serta bagian sistem mana yang harus dipertahankan

1. Kebutuhan Fungsional

Kebutuhan fungsional adalah kebutuhan - kebutuhan yang memiliki keterkaitan langsung dengan aplikasi. Kebutuhan fungsional meliputi :

a. Sistem informasi dapat melakukan entri data yang berhubungan dengan pengajuan pembelian stok barang.

b. Sistem Informasi dapat melakukan entri data yang berhubungan dengan permintaan permintaan stok barang.

c. Sistem Informasi dapat melakukan entri data yang berhubungan dengan stok barang.

d. Sistem Informasi dapat melakukan proses pencarian barang berdasarkan nomor barang.

e. Sistem Informasi dapat melakukan filter data sesuai dengan masing - masing departemen yang berhubungan dengan stok barang

f. Sistem Informasi dapat melakukan perhitungan cost atau biaya bulanan masing - masing departemen

g. Aplikasi dapat melakukan pencatatan laporan seperti : 1. Sistem Informasi data mencetak laporan list barang

2. Sistem Informasi dan mencetak laporan list supplier

3. Sistem Informasi data mencetak laporan list pengajuan pembelian barang sesuai departemen masing masing

4. Sistem Informasi data mencetak laporan list pengajuan permintaan stok barang sesuai departemen masing - masing

5. Sistem Informasi dapat mencetak laporan masukan stok barang.

6.Sistem Informasi dapat mencetak laporan pemakaian setiap departemen.

7.Sistem Informasi dapat mencetak laporan status barang yang terbaru.
2. Kebutuhan Non-Fungsional

Perangkat lunak merupakan perangkat yang berfungsi untuk melakukan pengerjaan dalam memproses sistem untuk mendukung pekerjaan sistem komputer. Agar sistem informasi ini dapat berjalan dengan baik, maka diperlukanlah beberapa perangkat lunak, yaitu :

a. Kebutuhan Perangkat Lunak (Software)

b. Perangkat lunak merupakan perangkat yang berfungsi untuk melakukan pengerjaan dalam memproses sistem untuk mendukung pekerjaan sistem komputer. Agar sistem informasi ini dapat berjalan dengan baik, maka diperlukanlah beberapa perangkat lunak, yaitu :

1. Microsoft Windows 7 atau 10

2. PhpMyAdmin

3. Java Runtime Environment

4. Xampp

c. Kebutuhan Perangkat Keras (Hardware)

Perangkat keras yang digunakan dalam penerapan sistem ini yaitu :

1. Komputer dengan spesifikasi : (i3/4Gb/500Gb)

2. Mouse

3. Keyboard

4. Barcode Scanner

5. Printer Inkjet

6. Switch LAN (Local Area Network)

7. Kabel LAN cat5 : 1 roll

8. Jack RJ45 : 1 box / 100 pcs

d. Kebutuhan Perangkat Manusia (Brainware)

1. Analisis Sistem

Yang bertugas untuk mempelajari dan menganalisa serta memberikan penjelasan terhadap suatu masalah untuk menyelesaikan dengan sistem.

2. Programmer

Yang bertugas melakukan penulisan ide - ide dan koding program komputer dan melakukan perancangan program sesuai dengan apa yang diarahkan oleh analisa sistem.

3. Operator

Yang bertugas mengoperasikan sistem yang telah dibuat berupa masukan (input), pengeditan (update), penghapusan (delete) dan pembuatan laporan yang dibantu dengan bantuan komputer.

\section{J. Perancangan Prosedur Permintaan Pembelian Barang}

Berikut prosesur yang diusulkan dalam proses permintaan pembelian barang dalam masing - masing departemen, prosedur ini diharapkan dapat memecahkan masalah dalam efisiensi waktu pada proses pengajuan permintaan pembelian barang di Hotel Nite \& Day Laguna Bintan - Tanjungpinang adapun prosedur yang diusulkan melalui beberapa tahap berikut antara lain :

1. Department melakukan input data ke "Sistem Informasi 
Manajemen Persediaan dan Pendistribusian Stok Barang Hotel Nite \& Day Laguna Bintan - Tanjungpinang" pada menu "Purchase Request" dan disimpan kedalam database dalam tabel "tb_purchase_request".

2. Hotel Manager akan menentukan persetujuan pembelian barang dengan mengubah status dari pending menjadi approved jika menyetujui pembelian barang, dan mengubah status ke rejected jika tidak menyetujui pembelian barang tersebut.

3. Purchasing akan melakukan pembelian barang sesuai list approve dari Manajer.

4. Purchasing akan mengupdate harga dan supplier dari masing - masing barang permintaan.

K. Perancangan Prosedur Permintaan Pengambilan Stok Barang

Berikut prosesur yang diusulkan dalam proses permintaan pengambilan stok barang dalam masing - masing departemen, prosedur ini diharapkan dapat memecahkan masalah dalam efisiensi waktu pada proses permintaan permintaan barang di Hotel Nite \& Day Laguna Bintan - Tanjungpinang adapun prosedur yang diusulkan melalui beberapa tahap berikut antara lain :

1. Department melakukan input data ke "Sistem Informasi Manajemen Persediaan dan Pendistribusian Stok Barang Hotel Nite \& Day Laguna Bintan - Tanjungpinang" pada menu "Store Requisition" dan disimpan kedalam database dalam tabel "tb_store_request".

2. Bagian akunting akan menentukan persetujuan pengambilan barang dengan mengubah status dari pending menjadi approved jika menyetujui pengambilan barang, dan mengubah status ke rejected jika tidak menyetujui pembelian barang tersebut.

3. Bagian gudang akan melakukan proses pengeluaran stok barang sesuai list approve dari bagian akunting dan meneruskan barang yang diminta departemen ke masing masing departemen peminta.

\section{Perancangan Prosedur Penerimaan Stok Barang}

Berikut prosesur yang diusulkan dalam proses penerimaan stok barang pada bagian gudang, prosedur ini diharapkan dapat memecahkan masalah dalam efisiensi dalam mengolah data stok barang pada proses penerimaan stok barang di Hotel Nite \& Day Laguna Bintan - Tanjungpinang adapun prosedur yang diusulkan melalui beberapa tahap berikut antara lain :

1. Supplier mengantarkan barang pesanan dari purchasing

2. Bagian gudang mengecek barang yang akan diterima sesuai dengan "Purchase Request" yang telah disetujui sebelumnya dan dengan nota pembelian dari supplier.

3. Bagian gudang menerima barang dan menandatangani nota pembelian dari supplier.

4. Bagian gudang menerima rangkapan nota pembelian yang telah ditanda tangani dari supplier.

5. Bagian gudang melakukan input data ke "Sistem Informasi Manajemen Persediaan dan Pendistribusian Stok Barang Hotel Nite \& Day Laguna Bintan Tanjungpinang" pada menu "Receiving" dan disimpan kedalam database pada table "tb_receiving".

6. Bagian gudang meneruskan nota pembelian barang ke bagian akunting.

7. Bagian akunting, purchasing dan bagian gudang akan melakukan proses pencetakan laporan dari "Purchase Request" hingga laporan penerimaan barang "Receiving".

\section{Perancangan Prosedur Penerimaan Stok Barang}

Berikut prosesur yang diusulkan dalam proses penerimaan stok barang pada bagian gudang, prosedur ini diharapkan dapat memecahkan masalah dalam efisiensi dalam mengolah data stok barang pada proses penerimaan stok barang di Hotel Nite \& Day Laguna Bintan - Tanjungpinang adapun prosedur yang diusulkan melalui beberapa tahap berikut antara lain :

1. Bagian gudang memberikan barang ke departemen peminta sesuai dengan data yang telah diisi ke "Store Requisition" dan yang telah disetujui oleh bagian akunting.

2. Departemen peminta mengecek kesesuaian barang yang diberikan oleh bagian gudang dan menerima barang apabila sesuai.

3. Bagian gudang melakukan input data ke "Sistem Informasi Manajemen Persediaan dan Pendistribusian Stok Barang Hotel Nite \& Day Laguna Bintan Tanjungpinang" pada menu "Consume" dan disimpan kedalam database pada table "tb_consume".

4. Bagian gudang, akunting, dan departemen peminta akan melakukan pencetakan laporan dari "Store Requisition" hingga laporan pemakaian stok barang "Comsume" atas stok barang permintaan departemen yang telah diterima.

\section{N. Diagram Konteks}

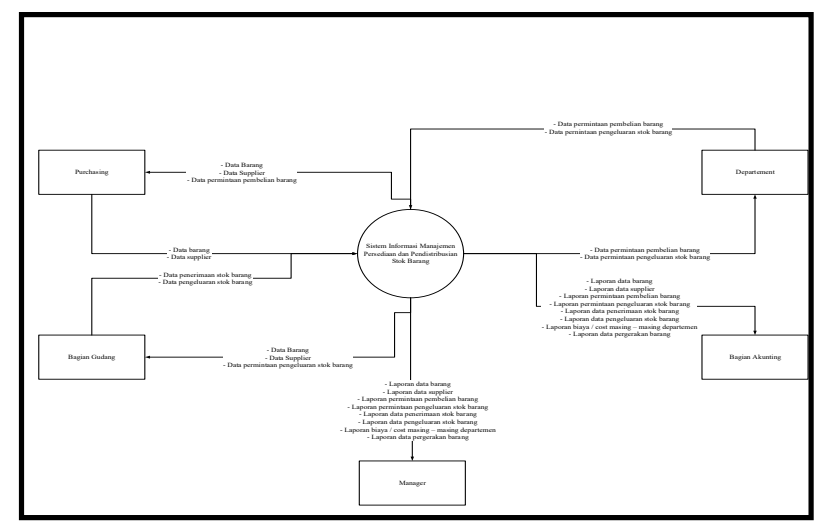

Gambar 2 Diagram Konteks

\section{O. Data Flow Diagram (DFD)}

DFD mengambarkan jaringan kerja antar fungsi yang berhubungan antara satu dengan yang lainnya dan menyimpan data sebagai perangkat analisis, model ini hanya mampu 
memodelkan sistem dari satu sudut pandangan yaitu : proses menunjukkan transportasi dari masukan menjadi keluaran, sejumlah mauskan dapat menjadi hanya satu keluaran atau sebaliknya. Aliran dari komponen ini diresresemtasikan dengan menggunakan panah yang menunjukkan menuju ke atau dari proses, penyimpanan yang memodelkan kumpulan data, dan terminator yang mewakili entity luar dimana sistem berkomunikasi.

5. DFD Level 1

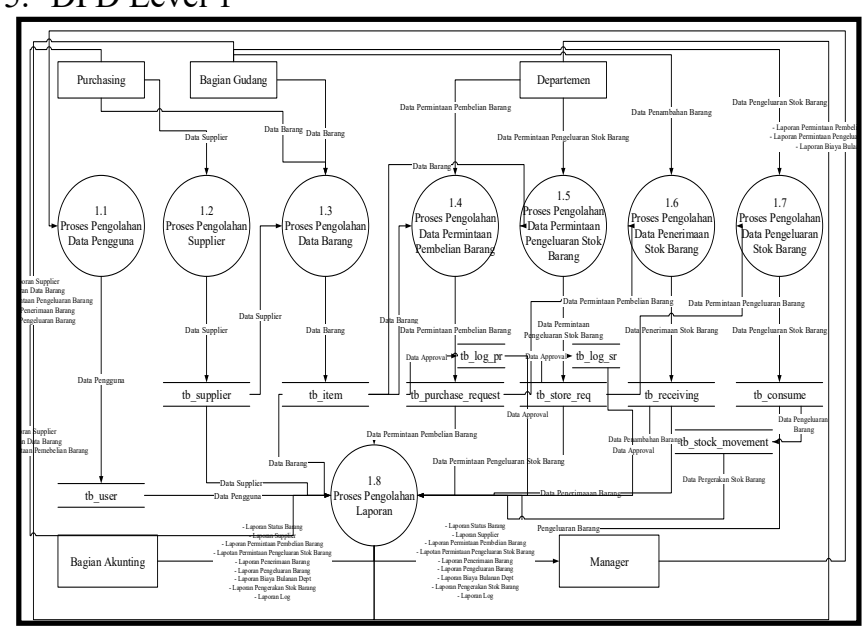

Gambar 3 DFD Level 1

6. DFD Level 1 Proses 1

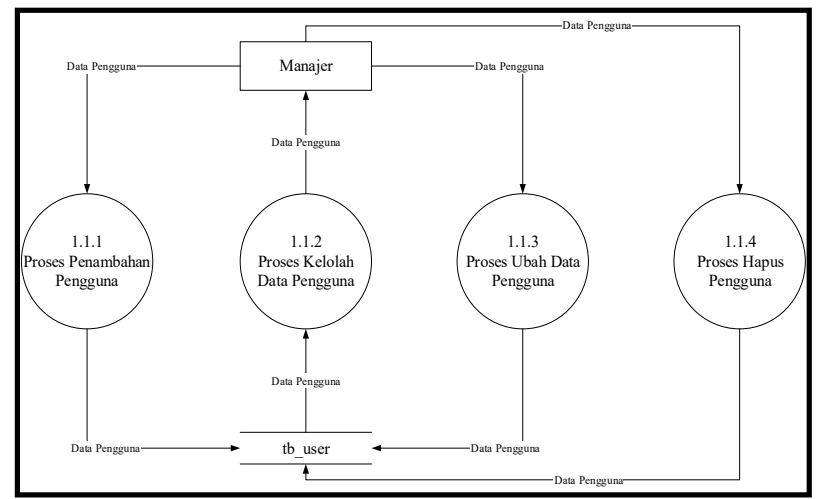

Gambar 4 DFD Level 1 Proses 1
7. DFD Level 1 Proses 2

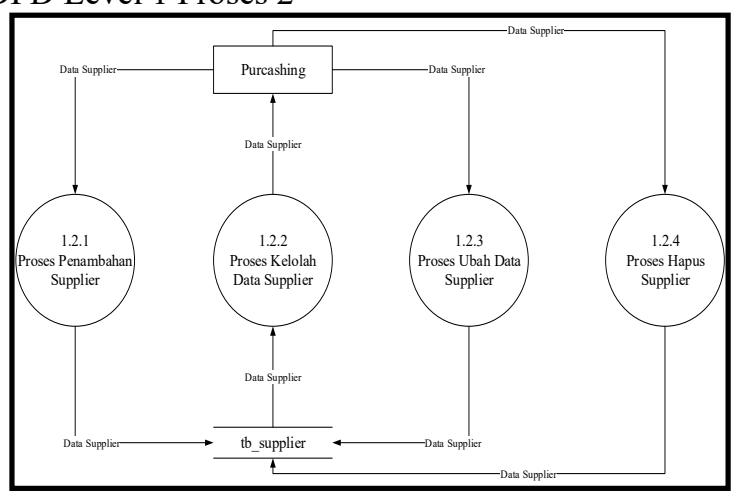

Gambar 5 DFD Level 1 Proses 2

8. DFD Level 1 Proses 3

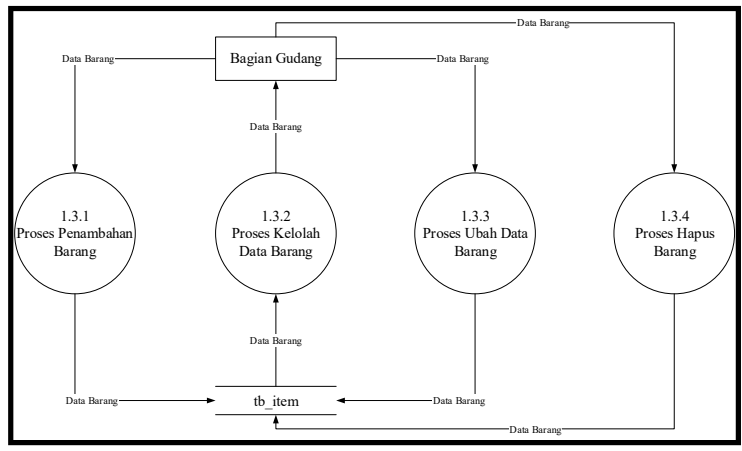

Gambar 6 DFD Level 1 Proses 3

9. DFD Level 1 Proses 4

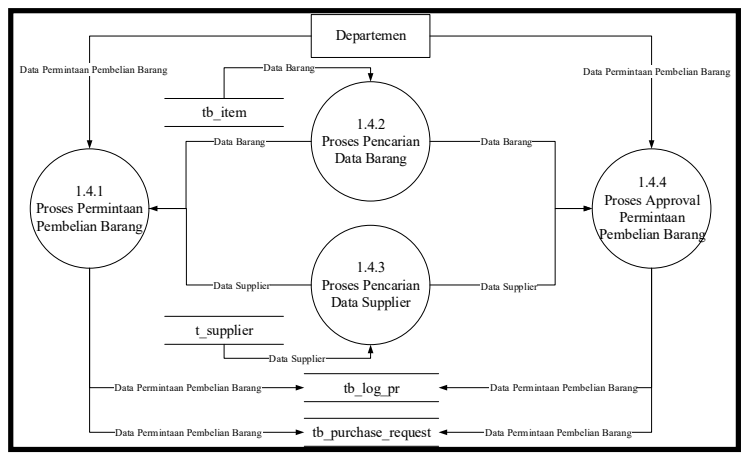

Gambar 7 DFD Level 1 Proses 4 


\section{DFD Level 1 Proses 5}

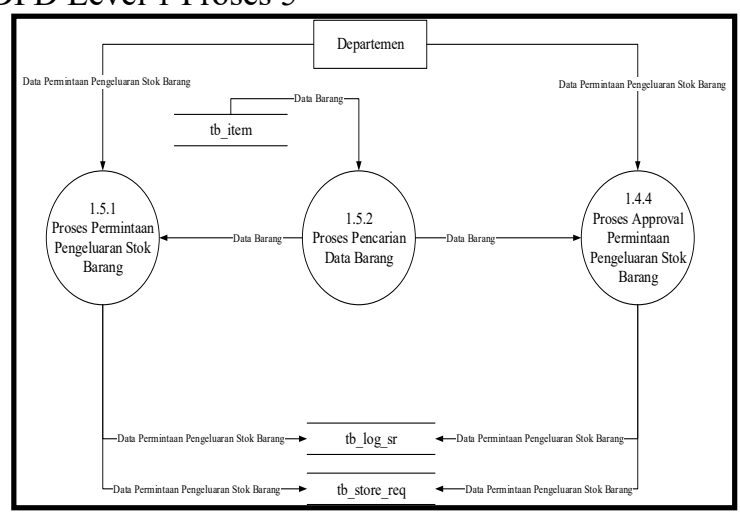

Gambar 8 DFD Level 1 Proses 5

\section{DFD Level 1 Proses 6}

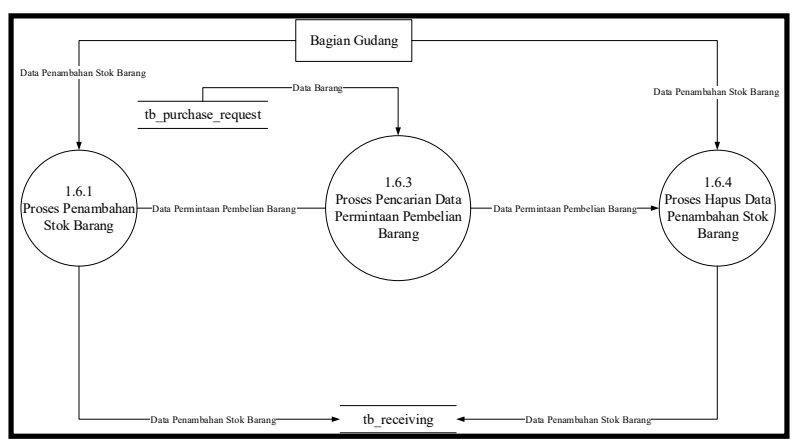

Gambar 9 DFD Level 1 Proses 6

\section{DFD Level 1 Proses 7}

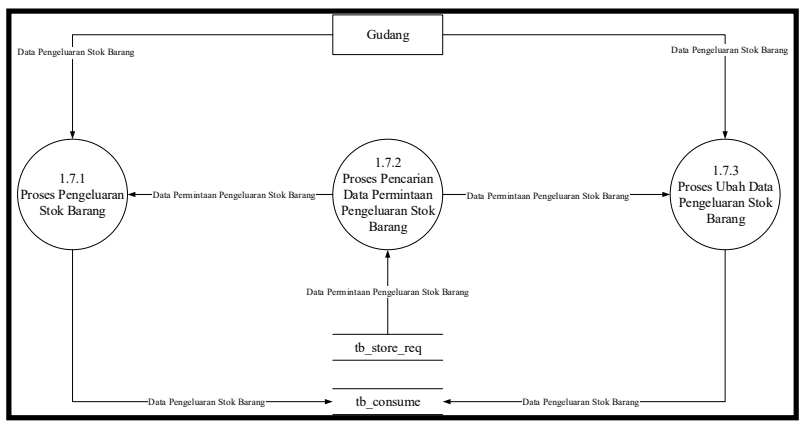

Gambar 10 DFD Level 1 Proses 7

13. DFD Level 1 Proses 8

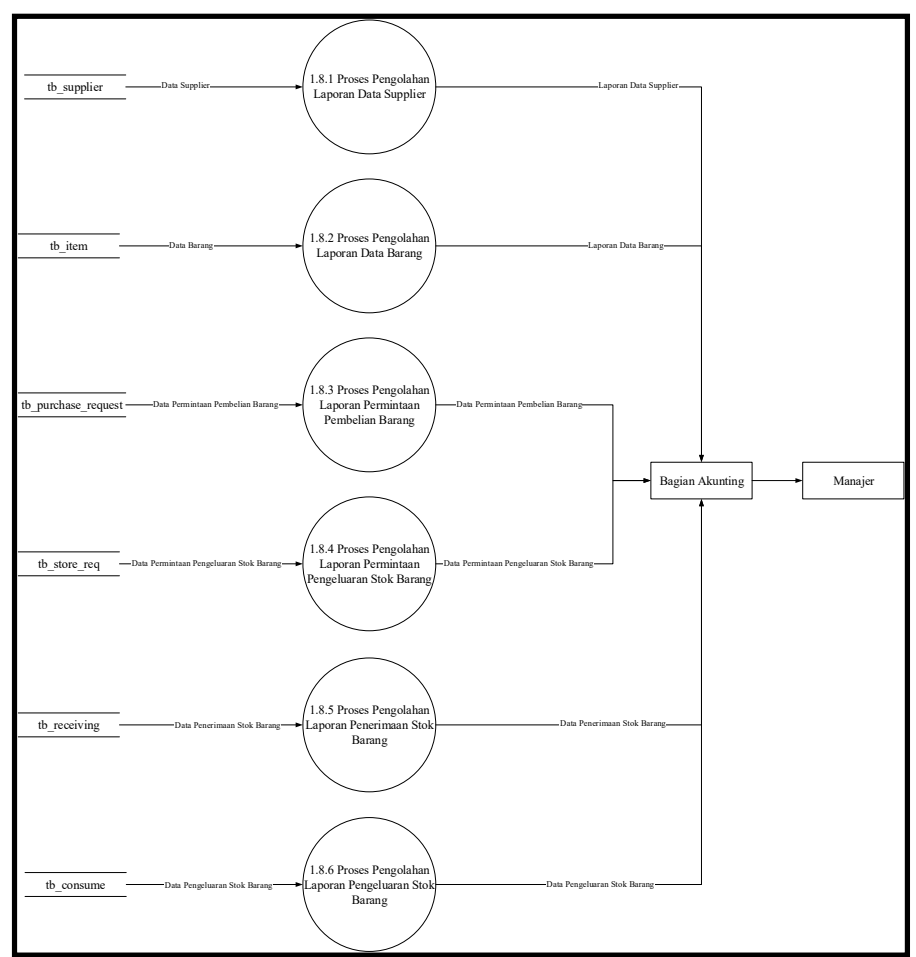

Gambar 11 DFD Level 1 Proses 8

P. Perancangan Struktur Program

Perancangan Struktur Program adalah suatu konsep pembuatan yang mempunyai fungsi untuk mengelompokkan instruksi kedalam sub program fungsional dimana setiap sub program tersebut memiliki tugas dan fungsi tertentu yang digunakan untuk mendukung dari keseluruhan program yang dibuat. Struktur program yang dibuat adalah sebagai berikut :

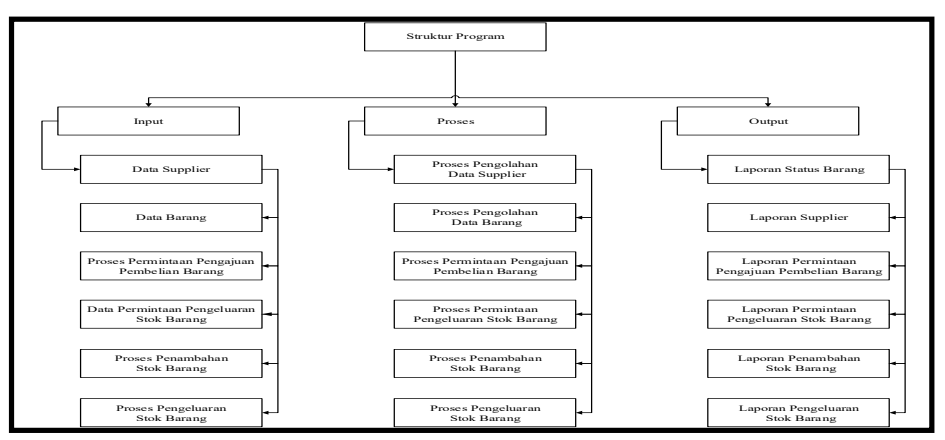

Gambar 4.12 Perancangan Struktur Program

\section{Q. Perancangan Struktur Menu}

Struktur menu adalah bentuk umum dari suatu rancangan program untuk memudahkan pemakai dalam menjalankan program komputer. Sehingga saat menjalankan program, pengguna tidak mengalami kesulitan dalam memilih menumenu yang diinginkan. Pada perancangan perangkat lunak ini 
dibuat menu seperti gambar dibawah ini

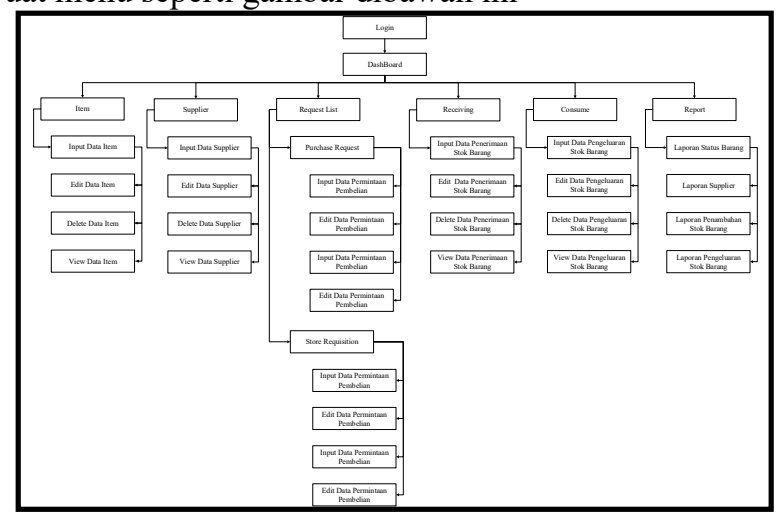

Gambar 13 Perancangan Struktur Menu

\section{R. Implementasi Sistem}

Implementasi merupakan langkah yang dilakukan setelah perencanaan dan pengujian aplikasi atau program. Pada tahapan ini sistem informasi yang telah dibangun akan diterapkan pada sistem yang lama sehingga dapat berjalan dengan baik dan optimal. Langkah - langkah yang dilakukan dalam implementasi ini adalah penyesuaian dengan kebutuhan dari perangkat lunak dan keras yang dibutuhkan untuk dapat mengoprasikan program ini.

\section{S. Batasan Implementasi}

Adapun batasan dalam mengimplementasikan sistem informasi yang telah dibuat. Batasan tersebut berupa hanya pada proses pengolahan data pengguna sistem informasi, proses pengelolaan data barang, proses pengolahan data supplier, proses pengolahan data permintaan pembelian barang, proses pengolahan data permitnaan pengeluaran stok barang, proses pengolahan data penerimaan stok barang, proses pengolahan data pengeluaran stok barang, dan proses pembuatan laporan.

\section{KESIMPULAN}

Sebagai akhir dari pembuatan laporan akhir skripsi ini penulis mencoba untuk mengambil kesimpulan secara umum terhadap materi keseluruhan yang menyangkut pelaksanaan Sistem Informasi Manajemen Persediaan dan Pendistribusian Stok Barang Nite \& Day Laguna Bintan - Tanjungpinang.

Setelah dilakukan penganalisaan terhadap prosedur saat manajemen, penerimaan, pengeluaran dan pendistribusian stok barang yang sedang berjalan, terlihat adanya hambatanhambatan yang menyebabkan terjadinya kesulitan dalam proses pengolahan penerimaan dan pengeluaran stok barang tersebut yang telah di lihat sebelumnya. Dalam hal ini penulis dapat mengmbil kesimpulan pada aplikasi yang dibuat sebagai berikut :
14. Dengan adanya sistem informasi

15. manajemen persediaan dan pendistribusian stok barang Nite \& Day Laguna Bintan - Tanjungpinang ini diharapkan dapat melakukan proses penerimaan dan penegeluaran lebih efektif.

16. Diharapkan adanya sistem informasi ini juga bisa melakukan pengolahan data barang dan supplier seperti pencarian, penghapusan, pengeditan dan pencetakan laporan di Hotel Nite \& Day Laguna Bintan Tanjungpinang secara terkomputerisasi

17. Dengan menggunakan sistem infromasi ini diharapkan proses - proses yang memerlukan laporan bulanan dan tahunan dapat diproses dengan cepat.

\section{REFERENSI}

[1] Nugroho, Adi. "Analisa dan Perancangan Sistem Informasi dengan Metodologi Berorientasi Objek". Informatika. 2004.

[2] Jesperson Hutahean, "Konsep Sistem Informasi”, [CV Budi Utama, 2014, Yogjakarta]

[3] Kadir, Abdul, "Konsep dan Tuntunan Praktis Basis Data", Penerbit Andi, Yogyakarta, 1999

[4] Pressman Roger S, "Rekayasa Perangkat Lunak Pendekatan Praktisi,Yogyakarta 2002

[5] Herjanto, Eddy, "Manajemen Operasi Edisi Ketiga", Grasindo, Jakarta, 2010

[6] Simarmata, Janner "Perancangan Basis Data", Andi 2007 Yogyakarta

[7] Aji, Dwi N, I. H. Al Amin, “Aplikasi CRM Pada Anto Stationery Dengan Metode FIFO”, 2018

[8] Prasojo dan Riyanto, Teknologi informasi pendidikan,2009

[9] Mustakini,Jogiyanto Hartono,Sistem Informasi Teknologi,2009

[10] Sommerville, "Software Engineering", 2011 